This is the author's manuscript for publication. The publisher-formatted version may be available through the publisher's web site or your institution's library.

\title{
Sublethal effects of chlorantraniliprole and thiamethoxam seed treatments when Lysiphlebus testaceipes feed on sunflower extrafloral nectar
}

Valéria F. Moscardini, Pablo C. Gontijo, J. P. Michaud, and Geraldo A. Carvalho

\section{How to cite this manuscript}

If you make reference to this version of the manuscript, use the following information:

Moscardini, V. F., Gontijo, P. C., Michaud, J. P., \& Carvalho, G. A. (2014). Sublethal effects of chlorantraniliprole and thiamethoxam seed treatments when Lysiphlebus testaceipes feed on sunflower extrafloral nectar. Retrieved from http://krex.ksu.edu

\section{Published Version Information}

Citation: Moscardini, V. F., Gontijo, P. C., Michaud, J. P., \& Carvalho, G. A. (2014). Sublethal effects of chlorantraniliprole and thiamethoxam seed treatments when Lysiphlebus testaceipes feed on sunflower extrafloral nectar. BioControl, 59(5), 503511.

Copyright: ( International Organization for Biological Control (IOBC) 2014

Digital Object Identifier (DOI): doi:10.1007/s10526-014-9588-5

Publisher's Link: http://link.springer.com/article/10.1007/s10526-014-9588-5

This item was retrieved from the K-State Research Exchange (K-REx), the institutional repository of Kansas State University. K-REx is available at http://krex.ksu.edu 
Sublethal effects of chlorantraniliprole and thiamethoxam seed treatments when Lysiphlebus testaceipes feed on sunflower extrafloral nectar

\section{Valéria F Moscardini, ${ }^{a, b}$ Pablo C Gontijo, ${ }^{\text {a,b }}$ JP Michaud ${ }^{\mathrm{b} *}$ and Geraldo A Carvalho ${ }^{a}$}

aDepartment of Entomology, Federal University of Lavras, Lavras, Minas Gerais, Brazil.

bDepartment of Entomology, Kansas State University, Agricultural Research CenterHays, Hays, Kansas, USA.

* Corresponding author: J.P. Michaud, 1232 240th Ave., Hays, KS, 67601, Email: jpmi@ksu.edu

\section{ABSTRACT}

The extrafloral nectar (EFN) of sunflower, Helianthus annuus L., is an important summer resource for many insects and represents a potential route of exposure to systemic insecticides applied as seed treatments to cultivated varieties. Among the many parasitoids that utilize sunflower EFN, Lysiphlebus testaceipes (Cresson) (Hymenoptera: Braconidae) is an important generalist parasitoid of cereal aphids in North America. This study evaluated the performance of adult wasps fed EFN of sunflower plants grown from seed treated with chlorantraniliprole and thiamethoxam. Consumption of EFN from treated sunflower seedings caused no lethal effects, but reduced the numbers of greenbug nymphs, Schizaphis graminum Rondani, attacked and parasitized when wasps foraged in Petri dish arenas. Whereas control females self-superparasitized every fourth host, those exposed to chlorantraniliprole did not. 
Offspring developmental time and adult emergence were unaffected by either treatment, but thiamethoxam greatly reduced the proportion of female offspring.

Keywords: conservation biological control, ecotoxicology, Lysiphlebus testaceipes (Hymenoptera: Braconidae), Schizaphis graminum, systemic insecticides

\section{Introduction}

Plants have evolved multiple strategies to defend themselves against herbivores. Aside from direct physical and chemical defences, nectar and pollen plants may attract natural enemies of their herbivores in addition to pollinators (Pemberton and Lee 1996; Nicolson et al. 2007). Both floral and extrafloral nectar (EFN) are an important source of hydration and nutrition for parasitoids (Heimpel and Collier 1996; Heimpel et al. 1997). The composition of EFN differs from that of floral nectar in most plant species (Baker et al. 1978). Although both are mostly sugar by weight, EFN usually contains a full complement of essential amino acids, albeit in low concentrations, with sucrose the dominant sugar, rather than glucose or fructose (Baker and Baker 1979; Rogers 1985). Sugars can be essential for parasitoid survival (Lewis et al. 1998), longevity (Dyer and Landis 1996) and fecundity (Olson and Andow 1998), and improve parasitoid performance in biological control contexts (Gurr et al. 2004). Another benefit of EFN is that it is available to natural enemies for a much longer period than floral nectar, beginning early in plant development and continuing up to, and beyond, flowering (Pacini et al. 2003; Rose et al. 2006). 
On the High Plains of the USA, sunflower plants are an important source of EFN for beneficial insects during the hot, dry summers (Royer and Walgenbach 1991). Small nectaries that occur profusely along petioles and leaf veins secrete nectar from the time the first true leaves expand until the plants senesce. A great diversity of parasitoids feed on sunflower EFN (e.g., Charlet and Gavloski 2011) and the presence of sunflowers has been shown to improve the area-wide survival of natural enemy species important in the biological control of key pests in neighboring crops (e.g., Brewer et al. 2008), probably by supplying critical resources for natural enemies (Gurr et al. 2004). Intercropping cultivated plants with EFN-producing companion plants has even been proposed to supplementary food for natural enemies early in the growing season before pests become abundant (Jamont et al. 2013).

Like many other row crops cultivated on the High Plains, the majority of commercial sunflower seed is now planted with a systemic insecticide seed treatment which poses a potential hazard to natural enemies. Seed treatments have been promoted as more compatible with biological control than broadcast sprays of insecticides, primarily because seed treatment involves a smaller amount of pesticide applied in a more selective manner, with consequently reduced impacts on non-target organisms (Hull and Beers 1985; Albajes et al. 2003) and lower levels of environmental contamination (Taylor et al. 2001). Systemic insecticides typically show low lipophilicity and exhibit a low octanol-water partition coefficient (log $\left.P_{\text {oct }}\right)$ (Cloyd and Bethke 2011). This property facilitates their translocation in plant tissues, and may lead to contamination of pollen, floral and EFN (Maienfisch et al. 2001; Lahm et al. 2009) that, in turn, can cause both lethal and sublethal effects on natural enemies over potentially 
prolonged periods (Lundgren 2009; Li et al. 2012). EFN is produced in much earlier stages of plant development than floral nectar and thus has the potential to bear higher concentrations of systemic insecticides applied as seed treatments. For example, residues of the neonicotinoid imidacloprid were 50 times more concentrated in cotyledons than in the first true leaves of sunflower, and 800 times more concentrated than in the apex of plant; concentrations were typically reduced by half in each successive pair of leaves, reflecting progressive dilution as a function of plant growth (Laurent and Rathahoa 2003).

Chlorantraniliprole and thiamethoxam represent two different systemic insecticide groups used in seed treatment, diamides and neonicotinoids, respectively. Diamide insecticides have a novel mode of action that acts exclusively on the ryanodine receptor in insect neuromuscular junctions (Nauen 2006; Lahm et al. 2009). In contrast, thiamethoxam is a neonicotinoid insecticide that targets nicotinic acetylcholine receptors in the insect central nervous system (Tomizawa and Casida 2005) and can be converted within the plant into highly toxic metabolites such as clothianidin (Casida 2011) which can increase its toxicity.

Lysiphlebus testaceipes (Cresson) (Hymenoptera: Braconidae) is a solitary endoparasitoid that attacks more than 100 aphid species, mostly on grasses and herbaceous plants (Pike et al., 2000). It is an important natural enemy of the greenbug, Schizaphis graminum (Rondani) (Hemiptera: Aphididae) and helps to maintain populations of this aphid below economic levels in both sorghum (Jones 2001) and wheat (Giles et al., 2003). Without nectar, many parasitoids show a dramatic reduction in their ability to parasitize insect pests (Stapel et al.1997; Lewis et al.1998), and adult 
L. testaceipes can often be observed feeding on sunflower EFN in the High Plains environment (J.P.M. unpublished observations). Therefore, the objectives of this study were to assess whether either chlorantraniliprole or thiamethoxam would have any impacts on the survival of adult wasps, their foraging behavior, or the development of their offspring, when the adults fed on EFN of sunflower seedings grown from treated seed.

\section{MATERIALS AND METHODS}

\subsection{Insect colonies}

All insect colonies were held in growth chambers under the same physical conditions: $21 \pm 1^{\circ} \mathrm{C}$ and a L:D 16:8 photoperiod. The colony of $S$. graminum was initiated from aphids naturally infesting sorghum in a greenhouse at the Agricultural Research Center-Hays, in Hays, KS, USA. The aphids were established on seedlings of a greenbug-susceptible sorghum variety (cv. P8500) planted in metal trays $(8.0 \mathrm{~cm} \mathrm{x}$ $51.0 \mathrm{~cm} \times 36.0 \mathrm{~cm})$ filled with a mixture of soil, peat moss and perlite $(1: 1: 1)$ and germinated in a greenhouse at $25 \pm 2{ }^{\circ} \mathrm{C}$. A colony of $L$. testaceipes was established from material obtained from a laboratory culture that had been maintained on Rhopalosiphum padi (L.) (Hemiptera: Aphididae) at the Department of Entomology, University of Minnesota, MN, USA for many generations. The colony was reared on $S$. graminum for three generations prior to use in bioassays. For each generation, mated parasitoid females (2-3 d old, $n=20$ ) were each provided ca. 50 2nd and 3rd instar aphids in a Petri dish $(5.5 \mathrm{~cm}$ diam) for a period of $50 \mathrm{~min}$ tallied from the time the first aphid was stung. Following removal of wasps, the aphids were transferred to sorghum 
seedlings in plastic pots $(15.0 \mathrm{~cm}$ diam $\times 14.0 \mathrm{~cm} \mathrm{ht}), \mathrm{ca} .250$ aphids per pot. The seedlings had been germinated in a mixture of soil, peat moss and perlite $(1: 1: 1)$ in a greenhouse at $25 \pm 2 \stackrel{\circ}{\circ}$. The pots were placed in a growth chamber and, once mummification of parasitized aphids occurred, mummies were removed from the plants and placed in a wax paper cup ( $8.5 \mathrm{~cm}$ diam $\times 12.5 \mathrm{ht})$ covered with a plastic Petri lid until adult emergence. Emergent adults were fed with a solution of diluted honey (50\%) streaked onto the plastic lid. Males and females were held together for ca. $48 \mathrm{~h}$ to permit mating before females were removed and used to produce the next generation.

\subsection{Sunflower plants}

Seeds of Pioneer 63N82 sunflower treated with chlorantraniliprole (1800 mg a.i. $100 \mathrm{~kg}^{-1}$ ) were provided by DuPont Crop Protection (division of E.I. du Pont de Nemours and Co., Wilmington, DE). Seeds of Triumph Nusun cv. 810CL were obtained from Triumph Seed Corp. (division of Dow Agrosciences, Indianapolis, ID) both with and without treatment with Cruiser $5 \mathrm{FS}{ }^{\circledR}$ (thiamethoxam, $50 \mathrm{mg}$ a.i. $100 \mathrm{~kg}^{-1}$, Syngenta Crop Protection, Greensboro, NC); untreated Triumph seed served as the experimental control. Seeds for each treatment were planted in separate metal trays $(8.0 \mathrm{~cm} \times 51.0$ $\mathrm{cm} \times 36.0 \mathrm{~cm})$ filled with a mixture of soil, peat moss and perlite $(1: 1: 1)$ and germinated in a greenhouse at $25 \pm 2 \stackrel{\circ}{ } \mathrm{C}$ under natural light supplemented during daylight hours with metal halide lamps ( $L: D=12: 12)$.. Plants were watered daily, but sparingly, to avoid excessive leaching of insecticide. Sunflower stalks were harvested beginning at the V2 stage (two true leaves expanded) and every two days thereafter throughout each period of parasitoid exposure in experimental treatments. This growth stage 
corresponded to $14-15 \mathrm{~d}$-old plants, post-emergence, under the prevailing temperature conditions. Sunflower plants begin secreting extrafloral nectar shortly about two weeks after germination, the first nectaries developing on the main stem between the cotyledons and the first true leaves. These small nectaries are invisible to the naked eye, but they occur profusely over the surface of stems, leaf petioles and leaf veins. The nectar is exuded in very small amounts from these tiny pores and it appears to require considerable feeding effort on the part of insects to obtain the EFN. For provisioning to insects, stem segments (ca. $10.0 \mathrm{~cm}$ long) were excised from seedlings and the cut ends dipped in liquid paraffin to seal vascular tissues and maintain turgor, while at the same time preventing the exudation of any resinous materials that might pose a hazard to the insects.

\subsection{Experimental procedure}

In order to test for lethal and sublethal effects of exposure to EFN form treated and untreated seedlings, mummies of $L$. testaceipes $(n=30)$ were placed in wax paper cups ( $n=4$ cups per treatment), each containing two sunflower stem segments and sealed with a plastic Petri dish lid. Upon emergence, the adult wasps were exposed to the sunflower stems as their only food source for a period of $48 \mathrm{~h}$, with all stems replaced after $24 \mathrm{~h}$. Mortality was then tallied after $48 \mathrm{~h}$ with cup as the experimental unit. Sublethal effects on behavior were assessed by aspirating individual females $(n=$ 16 per treatment) into Petri dishes (5.5 cm diam), each containing 40 2nd and $3 r d$ instar aphids. Following release of each female wasp, the time to first sting (attack latency) was recorded and the wasp was left to forage for $30 \mathrm{~min}$, whereupon the female was 
removed. All aphids from each dish were then transferred with a fine brush to a single sorghum seedling (one per replicate) that had been germinated in a $16.0 \mathrm{~cm}$ plastic cone (Stuewe \& Sons, Corvallis, OR) filled with a mixture of soil, peat moss and perlite (1:1:1). Wasps that did not sting an aphid within 10 min of release were replaced. Each cone was then covered with a custom-made, clear plastic cylinder (30 cm length), sealed at the top with a plastic plug and ventilated on the sides by means of a series of screened holes. The cones were inserted into a supporting rack and transferred to a growth chamber. Plants were watered every $48 \mathrm{~h}$ by submerging the rack of cones in a water bath for $30 \mathrm{~min}$. Four days after parasitism, a sample of aphids from each plant $(n=10)$ were dissected in saline under a stereo microscope (40 x magnification) to verify the presence/absence of parasitoid larvae. The attack rate was estimated as the sum of parasitized aphids (those containing a parasitoid larvae) and pseudoparasitized aphids (those with teratocytes present and evident deterioration of aphid embryos, but no parasitoid larva). Aphids containing more than one wasp larva were tallied as selfsuperparasitized. As mummies formed, they were carefully removed from plants and transferred to a wax paper cup (as above) until emergence of adults.

\subsection{Data analysis}

Data were subjected to one-way ANOVA and, when significant, means were separated using Fisher's LSD test $(\alpha=0.05)$ (PROC GLM; SAS Institute, 2008). Exposure cups were considered replicates for analysis of mortality during exposure; individual females as replicates for analysis of attack behavior, and sorghum seedlings each bearing the aphids exposed to a single female as replicates for analysis of 
progeny fitness. Attack latency data were $\log (x+1)$ transformed, whereas percentage data (percent hosts attacked, parasitized, and offspring emergence) were arcsine square root transformed to fit requirements for normality and homoscedasticity (PROC UNIVARIATE; SAS Institute, 2008); untransformed means are presented in figures and tables. Proportional data (self-superparasitism, mummification, and sex ratio $(\Sigma q / \Sigma$ (ㅇ $+\widehat{C}))$ were analyzed using the Chi-square, Goodness of Fit test $(\alpha=0.05)$ (PROC FREQ; SAS Institute, 2008).

\section{RESULTS}

Neither chlorantraniliprole nor thiamethoxam seed treatments produced mortality of L. testaceipes any higher than controls after $48 \mathrm{~h}$ when adults consumed the EFN of excised sunflower stem segments (percent mortality \pm SE: control $=20.8 \pm 5.0$; chlorantraniliprole $=18.3 \pm 7.5$; thiamethoxam $=19.2 \pm 6.4 ; F_{2,9}=0.04, P=0.961$ ) However, both insecticide treatments reduced the latent period to first sting, number of aphids stung, and number of aphids parasitized (Table 1). Self-superparasitism was reduced by the chlorantraniliprole treatment, indicating lower levels of oviposition, and thiamethoxam reduced the offspring sex ratio (proportion female). Neither the proportion of remaining aphids forming mummies, adult emergence, nor development time from parasitism to emergence, were significantly affected by either treatment (Table 2).

\section{DISCUSSION}


Although no direct wasp mortality was observed in this study, the consumption of EFN from sunflower seedlings treated with chlorantraniliprole and thiamethoxam caused various sublethal effects on $L$. testaceipes behavior and biological performance. Female wasps exposed to either material were faster to attack their first aphid compared to control females, although they attacked fewer aphids within the test period. These females displayed various combinations of erratic behavior, disorientated movements, and extended periods of antennation and ovipositor probing on the same host, suggesting impaired host acceptance behavior. We suspect that the time to first host encounter was faster for treated females because they moved randomly within the dish from time of introduction, whereas control wasps spent an initial period evaluating sensory cues asssociated with their surrounding environment prior to initiating search behavior. For example, Hopkinson et al. (2013) observed that female L. testaceipes foraging for Aphis gossypii Glover and Aphis craccivora (Koch) (Hemiptera: Aphididae) on cotton leaf discs required a mean of 14.7 and $16.4 \mathrm{~min}$, respectively, to attack their first host, illustrating how much time may be expended by these insects exploring a leaf surface prior to an initial host encounter. Therefore, it is reasonable to expect that other behavioral impairments might be evident in a more complex, natural environment, that would not be observed in the experimental arenas. The relatively short latent periods observed in the present study are likely the result of presenting hosts in a small arena in the absence of plant material or other cues such as honeydew. Residues of various insecticides are known to trigger changes in parasitoid mobility, orientation, feeding and parasitism ability (Desneux et al. 2007; Garcia 2011). Changes in foraging behavior and rates of parasitism were observed after Anagrus nilaparvatae (Pang and Wang) 
(Hymenoptera: Mymaridae) fed on a mixture of honey and imidacloprid (Liu et al. 2010) and subsequent work found similar effects of chlorantraniliprole on the same species (Liu et al. 2012). Both a bracon and an encyrtid parasitoid that fed on floral nectar of Eucalyptus trees treated with an imidacloprid soil drench suffered reduced survival and reproductive performance (Paine et al. 2011), although in this case the concentrations detected in nectar were more than double the LC50 values for these species. In a three year field study, cotton seeds treated with either imidicloprid or thiamethoxam reduced the season-long rate of whitefly, Bemisia tabaci (Hemiptera: Aleyrodidae), parasitism by a complex of three aphelinid parasitoids (Naveed 2010).

The similar reductions in parasitoid performance caused by the chlorantraniliprole and thiamethoxam treatments likely result from entirely different effects on the insects, as the former material interferes with muscle contraction, and the latter with neurotransmission. Chlorantraniliprole induces the ryanodine receptors to release stored calcium ions from the sarcoplasmic reticulum, causing impaired regulation of muscle contraction, paralysis and ultimately death in sensitive species (Cordova et al. 2006; Lahm et al. 2007). In contrast, thiamethoxam targets nicotinic acetylcholine receptors on the post-synaptic membranes of nerve cell junctions producing both lethal and sublethal neurological effects (Tomizawa and Casida 2005). Both materials appeared to lower the overall mobility of females, resulting in fewer host encounters during the test period, and consequently less parasitism. This can be construed to result entirely from impaired muscle function in the chlorantraniliprole treatment. However, the neurotoxic activity of thiamethoxam has the potential to both impede wasp motor functions and their sensory perception of cues involved in host 
evaluation and acceptance. Disruption of parasitoid sensory perception and motor function as a function of sublethal exposure to neurotoxic insecticides is well documented (Haynes 1988; Garcia 2011). For example, Komeza et al. (2001), studied Leptopilina boulardi (Hymenoptera: Figitidae) females exposed to the LD20 of the organophosphate chlorpyrifos and found them to be less efficient in finding host patches marked with kairomones, and exhibit longer patch residence times. In contrast, Delpuech et al. (2005) found that the congeneric Leptopilina heterotoma Thomson females responded to kairomones of Drosophila with greater arrestment following contact with chlorpyrifos and deltamethrin at LD20. Thus, either inhibitive or stimulative (hormoligosis) effects of neurotoxic insecticides may be observed at sublethal doses, depending on the insecticide and species of insect.

Self-superparasitism occurs when a female lays eggs in a host that she has previously parasitized (Waage, 1986). In contrast to control females that laid an additional egg in almost every fourth host, L. testaceipes females exposed to chlorantraniliprole did not engage in this behavior (Table 1). Although L. testaceipes is a solitary parasitoid and only one offspring can survive per host, there exist several potential payoffs for self-superparasitism. Aphid parasitoids such as L. testaceipes emerge with hundreds of eggs ready to lay and laying an additional egg in some hosts can improve a female's probability of host possession for her offspring if there is a risk of superparasitism by conspecific females (Michaud and Mackaeur, 1995). Although supernumerary larvae are eliminated, upon hatching, additional eggs release additional teratocytes critical to selective digestion of host tissues (Falabella et al 2000; Caccia et al 2012) and these may improve the survival of neonate parasitoids in their 
physiological struggle against host resistance mechanisms. For example, Bai and Mackaeur (1992) found that Aphidius ervi Halliday developing in superparasitized pea aphids, Acyrthosiphum pisum Harris, gained $14 \%$ more dry mass compared to those in singly-parasitized hosts, with no cost in additional developmental time. Similarly, Zhang et al. (2010) reported that oviposition of multiple eggs increased parasitism success of the solitary parasitoid Campoletis chlorideae Uchida (Hymenoptera: Ichneumonidae) in larvae of Mythimna separata Walker (Noctuidae: Lepidoptera). In keeping with the inference that self-superparasitism of some fraction of hosts is an adaptive 'insurance' strategy for solitary parasitoids, its absence in females exposed to chlorantraniliprole can be considered an abnormality likely to have adverse effects on female fitness, for example if the behavior is adaptive for improving offspring survival in hosts of marginal suitability.

The lack of any significant difference among treatments in the proportion of aphids mummified appears somewhat inconsistent with the results obtained from dissected subsamples, and likely reflects a bias toward sampling parasitized aphids during removal of these subsamples. In order to minimize disturbance of the remaining aphids, subsamples were removed from sorghum seedlings by gently tapping them over a sheet of paper and collecting the first ten aphids so dislodged. Many factors can potentially influence the dropping propensity of aphids from a plant, including parasitism (e.g. McAllister and Roitberg 1987). Thus, we suspect that parasitized aphids had greater dropping propensity than unparasitized aphids and were thus over-represented in the dissected samples and under-represented in the remaining fraction that was reared to mummification. 
Neither offspring survival nor their developmental time was affected by either seed treatment (Table 2), but the sex ratio (proportion female) was significantly reduced by the thiamethoxam treatment. In arrhenotokous Hymenoptera such as $L$. testaceipes, unfertilized eggs become males, so egg fertilization (and thus sex ratio) is actively controlled, and females may even selectively place fertilized eggs in better hosts (e.g. Srivastava and Singh 1995a). In aphidiine wasps, sex ratio can be diminished by various stressors such as high temperature (Deng and Tsai 1998; Matin et al. 2009), low temperature (Sigsgaard 2000; Mahi et al. 2014), multiple matings (Kant et al. 2012) and aging (Srivastava and Singh 1995b; Kant et al. 2013). Since the rate of mumification among aphids not harvested for dissection was similar across treatments, the lower sex ratio in the thiamethoxam treatment is most likely attributable to neurologic impairment of females that interfered to some extent with their ability to fertilize eggs. Since both parasitoid population growth and biological control efficacy hinge on numbers of parasitoid females, a reduction in sex ratio to only $11 \%$ female can be considered a highly adverse result.

In summary, many studies have emphasized that systemic insecticides used in seed treatments pose risks to beneficial species such as parasitoids (Prabhaker et al. 2011), predators (Al-Deeb et al. 2001; Moser and Obrycki 2009), and pollinators (Girolami et al. 2009) due to their translocation within plants and their potential contamination of pollen and nectar (Cloyd and Bethke, 2011). The treatment of seed with such insecticides is now a widespread practice in production agriculture because it can improve stand establishment in row crops by protecting germinating seeds and young seedlings. However, neonicotinoids are notoriously incompatible with integrated 
pest management (IPM) (Hutchins 2010), can accumulate in soils, and are prone to leaching into waterways (Goulson 2013). Furthermore, there are risks to pollinators associated with improper handling or disposal of residues during planting operations (Nuyttens et al. 2013). Work in soybean has questioned whether producers gain any significant benefits from seed treatments (Seagraves and Lundgren 2012). Producers buying factory-treated seed incur a control cost prior to suffering any pest infestation, an expense that is not recouped if economically damaging pests do not attack plants in early growth stages. Because seed treatments constitute a prophylactic control, they are not consistent with IPM principles that require assessment of pest numbers and projection of an economic impact prior to resorting to pesticide application (Stern et al. 1959). Further studies are warranted to determine just how compatible seed treatments are with IPM programs that rely on conservation biological control to any significant extent.

\section{References}

Al-Deeb MA, Wilde GE, Zhu KY (2001) Effect of insecticides used in corn, sorghum, and alfalfa on the predator Orius insidiosus (Hemiptera: Anthocoridae). J Econ Entomol 94:1353-1360

Albajes R, López C, Pons X (2003) Predatory fauna in cornfields and response to imidacloprid seed treatment. Journal of Economic Entomology 96:1805-1813

Bai B, Mackauer M (1992) Influence of superparasitism on development rate and adult size in a solitary parasitoid wasp, Aphidius ervi. Func Ecol 6:302-307 
Baker I, Baker HG (1979) Chemical constituents of the nectars of two Erythrina species and their hybrid. Ann Missouri Bot Gard 66:446-450

Baker HG, Opler PA, Baker I (1978) A comparison of amino-acid complements of floral and extrafloral nectars. Bot Gaz 139:322-332

Brewer MJ, Noma T, Elliott NC, Kravchenko AN, Hild AL (2008) A landscape view of cereal aphid parasitoid dynamics reveals sensitivity to farm- and region-scale vegetation structure. Eur J Entomol 105:503-511

Caccia S, Grimaldi A, Casartelli M, Falabella P, Eguileor M de, Pennacchio F, Giordana B (2012) Functional analysis of a fatty acid binding protein produced by Aphidius ervi teratocytes. J Ins Physiol 58:621-627

Casida JE (2011) Neonicotinoid metabolism: compounds, substituents, pathways, enzymes, organisms, and relevance. J Agr Food Chem 59:2923-2931

Charlet LD, Gavloski J (2011) Insects of sunflower in the Northern Great Plains of North America. In: Floate KD (ed) Arthropods of canadian grasslands: inhabitants of a changing landscape, vol 2. Biological Survey of Canada, pp 159-178

Cloyd RA, Bethke JA (2011) Impact of neonicotinoid insecticides on natural enemies in greenhouse and interiorscape environments. Pest Manag Sci 67:3-9

Cordova D, Benner EA, Sacher MD, Rauh JJ, Sopa JS, Lahm GP, Selby TP, Stevenson TM, Flexner L, Gutteridge S, Rhoades DF, Wu L, Smith RM, Tao Y (2006) Anthranilic diamides: A new class of insecticides with a novel mode of action, ryanodine receptor activation. Pestic Biochem Phys 84:196-214 
Delpuech JM, Bardon C, Bouletreau M (2005) Increase of the behavioral response to kairomones by the parasitoid wasp Leptopilina heterotoma surviving insecticides. Arch Environ Con Tox 49:186-191

Deng YX, Tsai JH (1998) Development of Lysiphlebia japonica (Hymenoptera: Aphidiidae), a parasitoid of Toxoptera citricida (Homoptera: Aphididae) at five temperatures. Fla Entomol 81:415-423

Desneux N, Decourtye A, Delpuech JM (2007) The sublethal effects of pesticides on beneficial arthropods. Annu Rev Entomol 52:81-106

Dyer LE, Landis DA (1996) Effects of habitat, temperature, and sugar availability on Iongevity of Eriborus terebrans (Hymenoptera: Ichneumonidae). Environ Entomol 25:1192-1201

Falabella P, Tremblay E, Pennacchio F (2000) Host regulation by the aphid parasitoid Aphidius ervi: the role of teratocytes. Entomol Exp Appl 97:1-9

Garcia P (2011) Sublethal effects of pyrethroids on insect parasitoids: what we need to further know. In: Stoytcheva M (ed) Pesticides - Formulations, Effects, Fate. InTech, Rijeka, Croatia, pp 477-494

Giles KL, Jones DB, Royer TA, Elliott NC, Kindler SD (2003) Development of a sampling plan in winter wheat that estimates cereal aphid parasitism levels and predicts population suppression. J Econ Entomol 96:975-982

Girolami V, Mazzon L, Squartini A, Mori N, Marzaro M, Di bernardo A, Greatti M, Giorio C, Tapparo A (2009) Translocation of neonicotinoid insecticides from coated seeds to seedling guttation drops: a novel way of intoxication for bees. J Econ Entomol 102:1808-1815 
Goulson D (2013) REVIEW: An overview of the environmental risks posed by neonicotinoid insecticides. J Appl Ecol 50:977-987

Gurr GM, Scarratt SL, Wratten SD, Berndt L, Irvin NA (2004) Ecological engineering, habitat manipulation and pest management. In: Gurr GM, Wratten SD, Altieri MA (eds) Ecological Engineering for Pest Management. Comstock Press, Ithaca, pp. $1-12$

Haynes KF (1988) Sublethal effects of neurotoxic insecticides on insect behavior. Annu Rev Entomol 33:149-168

Heimpel GE, Collier TR (1996) The evolution of host-feeding behaviour in insect parasitoids. Biol Rev 71:373-400

Heimpel GE, Rosenheim JA, Kattari D (1997) Adult feeding and lifetime reproductive success in the parasitoid Aphytis melinus. Entomol Exp Appl 83:305-315

Hopkinson JE, Zalucki MP, Murray DAH (2013) Host selection and parasitism behavior of Lysiphlebus testaceipes: role of plant, aphid species and instar. Biol Control 64:283-290

Hull L, Beers E (1985) Ecological selectivity: modifying chemical control practices to preserve natural enemies. In: Hoy MA, Herzog DC (eds) Biological control in agricultural IPM systems. Academic Press, New York, pp. 103-122

Hutchins SH (2010) Indifference analysis: a practical method to assess uncertainty in IPM decision making. J Integ Pest Manag 1:D1-D3

Jamont M, Crépellière S, Jaloux B (2013) Effect of extrafloral nectar provisioning on the performance of the adult parasitoid Diaeretiella rapae. Biol Control 65:271-277 
Jones DB (2001) Natural enemy thresholds for greenbug, Schizaphis graminum Rondani, on winter wheat. Oklahoma State University, Stillwater, OK Kant R, Trewick SA, Sandanayaka WRM, Godfrey AJR, Minor MA (2012) Effects of multiple matings on reproductive fitness of male and female Diaeretiella rapae. Entomol Exp Appl 145:215-221

Kant R, Minor MA, Sandanayaka WRM, Trewick SA (2013) Effects of mating and oviposition delay on parasitism rate and sex allocation behaviour of Diaeretiella rapae (Hymenoptera: Aphidiidae). Biol Control 65: 265-270

Komeza N, Fouillet P, Bouletreau M, Delpuech JM (2001) Modification, by the insecticide chlorpyrifos, of the behavioral response to kairomones of a parasitoid wasp, Leptopilina boulardi. Arch Environ Con Tox 41:436-442

Lahm GP, Cordova D, Barry JD (2009) New and selective ryanodine receptor activators for insect control. Bioorg Med Chem 17:4127-4133

Lahm GP, Stevenson TM, Selby TP, Freudenberger JH, Cordova D, Flexner L, Bellin CA, Dubas CM, Smith BK, Hughes KA, Hollingshaus JG, Clark CE, Benner EA (2007) Rynaxypyr: a new insecticidal anthranilic diamide that acts as a potent and selective ryanodine receptor activator. Bioorg Med Chem Lett 17:6274-6279 Laurent FM, Rathahao E (2003) Distribution of [14C] imidacloprid in sunflowers (Helianthus annuus L.) following seed treatment. J Agric Food Chem 51:80058010

Lewis WJ, Stapel JO, Cortesero AM, Takasu K (1998) Understanding how parasitoids balance food and host needs: importance to biological control. Biol Control $11: 175-183$ 
Li X, Degain BA, Harpold VS, Marcon PG, Nichols RL, Fournier AJ, Naranjo SE, Palumbo JC, Ellsworth PC (2012) Baseline susceptibilities of B- and Q-biotype Bemisia tabaci to anthranilic diamides in Arizona. Pest Manag Sci 68:83-91

Liu F, Bao SW, Song Y, Lu HY, Xu JX (2010) Effects of imidacloprid on the orientation behavior and parasitizing capacity of Anagrus nilaparvatae, an egg parasitoid of Nilaparvata lugens. BioControl 55:473-483

Liu F, Zhang X, Gui Q-Q, Xu Q-J (2012) Sublethal effects of four insecticides on Anagrus nilaparvatae (Hymenoptera: Mymaridae), an important egg parasitoid of the rice planthopper Nilaparvata lugens (Homoptera: Delphacidae). Crop Prot $37: 13-19$

Lundgren JG (2009) Relationships of natural enemies and non-prey foods. Springer International, Dordrecht, Netherlands

Mahi H, Rasekh A, Shishehbor P, Michaud JP (2014) The biology of Lysiphlebus fabarum (Braconidae, Aphidiinae) following cold storage of larvae and pupae under various thermal regimes. Entomol Exp Appl (in press).

Maienfisch P, Angst M, Brandl F, Fischer W, Hofer D, Kayser H, Kobel W, Rindlisbacher A, Senn R, Steinemann A, Widmer Hr (2001) Chemistry and biology of thiamethoxam: a second generation neonicotinoid. Pest Manag Sci 57:901-913 Matin SB, Sahragard A, Rasoolian G (2009) Some biological parameters of Lysiphlebus fabarum (Hymenoptera: Aphidiidae) a parasitoid of Aphis fabae (Homoptera: Aphidiidae) under labaratory conditions. Munis Entomol Zool 4:193-200 McAllister MK, Roitberg BD (1987) Adaptive suicidal behavior in pea aphids. Nature 328:797-799 
Michaud JP, Mackauer M (1995) Oviposition behavior of Monoctonus paulensis (Hymenoptera: Aphidiidae): factors influencing reproductive allocation to hosts and host patches. Ann Entomol Soc Am 88:220-226

Moser SE, Obrycki JJ (2009) Non-target effects of neonicotinoid seed treatments; mortality of coccinellid larvae related to zoophytophagy. Biol Control 51:487-492 Nauen R (2006) Insecticide mode of action: return of the ryanodine receptor. Pest Manag Sci 68:690-692

Naveed M, Salam A, Saleem MA, Rafiq M, Hamza A (2010) Toxicity of thiamethoxam and imidacloprid as seed treatments to parasitoids associated to control Bemisia tabaci. Pak J Zool 42:559-565

Nicolson S, Nepi I, Pacini E (2007) Nectaries and Nectar. Springer-Verlag, Heidelberg

Nuyttens D, Devarrewaere W, Verboven P, Foque D (2013) Pesticide-laden dust emission and drift from treated seeds during seed drilling: a review. Pest Manag Sci 69:564-575

Olson DM, Andow DA (1998) Larval crowding and adult nutrition effects on longevity and fecundity of female Trichogramma nubilale Ertle \& Davis (Hymenoptera: Trichogrammatidae). Environ Entomol 27:507-512

Pacini E, Nepi M, Vesprini JL (2003) Nectar biodiversity: a short review. Plant Syst Evol 238:7-21

Paine TD, Hanlon CC, Byrne FJ (2011) Potential risks of systemic imidacloprid to parasitoid natural enemies of a cerambycid attacking Eucalyptus. Biol Control $56: 175-178$ 
Pemberton RW, Lee JH (1996) The influence of extrafloral nectaries on parasitism of an insect herbivore. Am J Bot 83:1187-1194

Pike KS, Stary P, Miller T, Graf G, Allison D, Boyd-ston L, Miller R (2000) Aphid parasitoids (Hymenoptera: Braconidae: Aphidiinae) of northwest USA. P Entomol Soc Wash 102:688-740

Prabhaker N, Castle SJ, Naranjo SE, Toscano NC, Morse JG (2011) Compatibility of two systemic neonicotinoids, imidacloprid and thiamethoxam, with various natural enemies of agricultural pests. J Econ Entomol 104:773-781

Rogers CE (1985) Extrafloral nectar: ecological implications. Bull Entomol Soc Am $31: 15-20$

Rose USR, Lewis J, Tumlinson JH (2006) Extrafloral nectar from cotton (Gossypium hirsutum) as a food source for parasitic wasps. Funct Ecol 20:67-74

Royer TA, Walgenbach DD (1991) Predacious arthropods of cultivated sunflower in Eastern South Dakota. J Kansas Entomol Soc 64:112-116

SAS Institute (2008) SAS for Windows Version 9.0. SAS Institute, Cary

Seagraves MP, Lundgren JG (2012) Effects of neonicitinoid seed treatments on soybean aphid and its natural enemies. J Pest Sci 85:125-132

Sigsgaard S. (2000) The temperature-dependent duration of development and parasitism of three cereal aphid parasitoids, Aphidius ervi, A. rhopalosiphi, and Praon volucre. Entomol Exp Appl 95:173-184

Srivastava M, Singh R (1995a) Sex ratio adjustment by a koinobiotic parasitoid Lysiphlebus delhiensis (Subba Rao \& Sharma) (Hymenoptera: Aphidiidae) in response to host size. Biol Agric Hort 12:15-28 
Srivastava M, Singh R (1995b) Influence of age of parents Lysiphlebus delhiensis (Subba Rao and Sharma) (Hym., Aphidiidae) during copulation on progeny production and offspring sex ratio. J Appl Entomol 119:72-77

Stapel JO, Cortesero AM, De Moraes CM, Tumlinson JH, Lewis WJ (1997) Extrafloral nectar, honeydew, and sucrose effects on searching behavior and efficiency of Microplitis croceipes (Hymenoptera: Braconidae) in cotton. Environ Entomol 26:617-623

Stern VM, Smith RF, van den Bosch R, Hagen KS (1959) The Integrated Control Concept. Hilgardia 29:81-101

Taylor AG, Eckenrode CJ, Straub RW (2001) Seed coating technologies and treatments for onion: Challenges and progress. HortScience 36:199-205

Tomizawa M, Casida JE (2005) Neonicotinoid insecticide toxicology: mechanisms of selective action. Annu Rev Pharmacol 45:247-268

Waage JK (1986) Family planning in parasitoids: adaptative patterns of progeny and sex allocation. In: Waage JK, Greathead D (eds) Insect Parasitoids. Academic Press, London, pp. 63-95

Zhang JH, Gu LQ, Wang CZ (2010) Superparasitism behavior and host discrimination of Campoletis chlorideae (Ichneumonidae: Hymenoptera) toward Mythimna separata (Noctuidae: Lepidoptera). Environ Entomol 39:1249-1254 
Table 1. Mean ( $\pm \mathrm{SE}$ ) parameters of Lysiphlebus testaceipes parasitism behavior when females were subjected to three treatments (wasps fed for $48 \mathrm{~h}$ on extrafloral nectar of sunflower stems excised from seedlings grown from seed treated with either chlorantraniliprole or thiamethoxam, or controls) prior to foraging as individuals on 40 second and third instar nymphs of Schizaphis graminum in a plastic Petri dish for $30 \mathrm{~min}$. Ten aphids were dissected from each replicate to determine percentages attacked and parasitized, and the proportion self-superparasitized.

\begin{tabular}{lllll}
\hline Seed treatment & Attack latency $^{1}(\mathrm{~min})$ & Percent attacked $^{1}$ & Percent parasitized $^{1}$ & Self-superparasitism $^{2 *}$ \\
\hline Control & $3.0 \pm 0.7 \mathrm{a}$ & $43.1 \pm 7.4 \mathrm{a}$ & $38.8 \pm 7.9 \mathrm{a}$ & $0.24 \pm 0.05 \mathrm{a}$ \\
Chlorantraniliprole & $1.5 \pm 0.4 \mathrm{~b}$ & $21.9 \pm 6.0 \mathrm{~b}$ & $19.4 \pm 5.7 \mathrm{~b}$ & $0.00 \pm 0.00 \mathrm{~b}$ \\
Thiamethoxam & $1.1 \pm 0.3 \mathrm{~b}$ & $24.4 \pm 5.2 \mathrm{~b}$ & $20.6 \pm 5.0 \mathrm{~b}$ & $0.09 \pm 0.05 \mathrm{ab}$ \\
For $\chi^{2}$ & 4.55 & 4.39 & 3.56 & 10.86 \\
d.f. & 2,45 & 2,45 & 2,45 & 2 \\
$P$ & 0.016 & 0.018 & 0.037 & 0.004 \\
\hline
\end{tabular}

Analysis by one-way ANOVA $\left({ }^{1}\right)$, or Chi-square $\left({ }^{2}\right)$.

Means $( \pm$ SE) and proportions followed by different letters were significantly different within columns (Fisher's LSD, or Chi-square, $\alpha=0.05$ ).

*Proportion of dissected hosts that contained two larvae. 
Table 2. Mean ( \pm SE) developmental parameters of Lysiphlebus testaceipes progeny whose mothers were subjected to three treatments (wasps fed for $48 \mathrm{~h}$ on extrafloral nectar of sunflower stems excised from seedlings grown from seed treated with either chlorantraniliprole or thiamethoxam, or controls) prior to parasitizing second and third instar nymphs of Schizaphis graminum in a plastic Petri dish.

\begin{tabular}{llllc}
\hline Seed treatment & $\begin{array}{c}\text { Proportion aphids } \\
\text { mummified }^{2}\end{array}$ & Adult emergence $^{1}(\%)$ & Development time $^{1}(\mathrm{~d})$ & $\begin{array}{c}\text { Sex ratio }^{2} \\
\text { (proportion female) }\end{array}$ \\
\hline Control & $0.25 \pm 0.02 \mathrm{a}$ & $82.2 \pm 5.2 \mathrm{a}$ & $15.7 \pm 0.2 \mathrm{a}$ & $0.41 \pm 0.05 \mathrm{a}$ \\
Chlorantraniliprole & $0.19 \pm 0.02 \mathrm{a}$ & $79.3 \pm 7.9 \mathrm{a}$ & $15.8 \pm 0.2 \mathrm{a}$ & $0.40 \pm 0.06 \mathrm{a}$ \\
Thiamethoxam & $0.21 \pm 0.02 \mathrm{a}$ & $72.6 \pm 4.2 \mathrm{a}$ & $15.5 \pm 0.1 \mathrm{a}$ & $0.11 \pm 0.04 \mathrm{~b}$ \\
$F$ or $\chi^{2}$ & 4.19 & 0.71 & 0.74 & 20.15 \\
d.f. & 2 & 2,35 & 2,35 & 2 \\
$P$ & 0.123 & 0.498 & 0.485 & $<0.001$ \\
\hline
\end{tabular}

Data were analyzed by one-way ANOVA ( $\left.{ }^{1}\right)$, or Chi-square $\left({ }^{2}\right)$.

Values followed by different letters were significantly different within columns (Chi-square, $\alpha=0.05$ ). 


\section{Acknowledgements}

The authors are grateful to the CAPES Foundation (Brazilian Ministry of Education), the National Council of Scientific and Technological Development (CNPq), and the Minas Gerais State Foundation for Research Aid (FAPEMIG) for scholarship support from CAPES - no. 336213-2 (VFM) and CAPES - no. 3363-13-9 (PCG). This is contribution no. 14-325-J of the Kansas State Experiment Station. 